\title{
Financial Reporting Quality and Online Disclosure Practices in Spanish Governmental Agencies
}

\author{
Javier Garcia-Lacalle * and Lourdes Torres
}

Faculty of Economics and Business, Universidad de Zaragoza, 50005 Zaragoza, Spain; 1torres@unizar.es

* Correspondence: jlacalle@unizar.es

\begin{abstract}
Good governance in the public sector implies high accountability levels. Accountability is a multidimensional concept that includes the quantity and reliability of disclosures as well as rendering accounts to the citizenry. Nowadays, good governance, accountability, and financial performance are key for the long-term sustainability of autonomous public sector organizations. The objective of this paper is to study how key governance features relate to the quantity and quality of the information disclosed. In particular, how the governing body, financial performance and organizational features relate to online transparency and financial reporting quality, as well as how these two accountability dimensions are related. To fulfill this objective, we have used the Structural Equation Modeling, Partial Least Squares (PLS-SEM) approach. The focus of our analyses is on Spanish central government agencies. The size of, and a greater presence of independent members in, the governing body are explanatory factors behind the quality of the financial reports. Our findings also show that the quality of the financial information is also affected by the pressure that Eurostat requirements -deficit limits- puts on public sector entities, which leads to the use of smoothing practices. Online disclosure practices are not explained by the features of the governing body, but by the size of the agencies and their financial results. The better the financial reporting quality, the higher the online disclosure levels.
\end{abstract}

Citation: Garcia-Lacalle, J.; Torres, L. Financial Reporting Quality and Online Disclosure Practices in Spanish Governmental Agencies. Sustainability 2021, 13, 2437. https://doi.org/10.3390/su13052437

Academic Editor: Ştefan Cristian Gherghina

Received: 21 December 2020 Accepted: 19 February 2021 Published: 24 February 2021

Publisher's Note: MDPI stays neutral with regard to jurisdictional claims in published maps and institutional affiliations.

Keywords: governing body; online disclosures; central government agencies; financial information quality; earnings management

\section{Introduction}

A major reason for the research interest in governance practices is the increase in demand for greater managerial accountability and responsibility after a number of accounting scandals [1]. Most of this research has focused on the features of the board of directors, because it plays a key role in the development internal control systems [2] and accountability levels [3]. Research has shown the positive effect of good governance practices on transparency, financial performance, financial reporting and holding managers accountable (see e.g., $[4,5]$ ).

Initiatives for developing guidelines and better practices in public sector governance have been in the agenda of most Western countries for more than 25 years, for improving stakeholder engagement and demonstrating that public entities have reliable administrative structures that enable them to be efficient and effective. In 1995, the Chartered Institute of Public Finance and Accountancy [6] concluded that the Cadbury Report on governance in corporations was also relevant to public sector organizations and urged them to adopt it. Core governance aspects include accountability, transparency, integrity stewardship, leadership and efficiency [7]. These aspects are classified into two groups: conformance and performance $[8,9]$. Conformance deals with monitoring and supervising executive performance and maintaining accountability. Performance deals with strategy and policy-making.

The most frequent approach in the academic literature to the study of the relationship between conformance and performance is to focus on one aspect of these two broad 
governance dimensions. Including an approach which includes these two dimensions in the analysis of governance mechanisms and its effects provides insights to their functioning in the public sector setting. The focus of our study is on the Spanish central governmental agencies. Our objective is to observe the relationships between governance dimensions in a comprehensive model, which allows us to better understand how they develop in the public sector. In this paper, we use Structural Equation Modeling, the Partial Least Squares approach (PLS-SEM), to study governance more comprehensively in Spanish central government agencies. In particular, the conformance characteristic of governance is studied considering the amount of online disclosures and the quality of the financial statements reported, as key elements of accountability. Accountability, a key conformance dimension, is closely linked in the public sector to the asymmetry of information between ministers, managers and stakeholders, which, in the public sector, has been shown to be more complex than in the private sector, open-ended or not explicitly defined and, thus, not easily monitored [10]. Accountability in the public sector, a multidimensional concept that includes, among other aspects, the quality and reliability of disclosures, is improved by reducing information asymmetry [11,12]. The performance characteristic of governance is studied considering the characteristics of the governing body, organizational features, and financial performance. PLS-SEM allows researchers to study complex relationships between variables, including several dependent and independent variables.

The paper is structured as follows. Section 2 is devoted to presenting the theoretical framework of our study. In Section 3 hypotheses are drawn. Section 4 briefly describes the context of the Spanish central government agencies. Section 5 explains the research design and the methodology used. Section 6 presents our results, which are discussed in Section 7. Finally, conclusions are drawn in Section 8.

\section{A Multi-Theoretical Framework for Sustainability in the Public Sector}

Agency theory suggests that the disclosure of information is a means of enhancing accountability by reducing the information asymmetry between principals and agents, managers being accountable to principals. The accountability relationship is characterized by the focus of the principal on controlling the agent, because agents have more information than principals, which can be exploited for self-gain $[13,14]$. Citizens are considered the principal, and the public entities' managers act as their agent to protect the public interest $[15,16]$. However, according to Calabro et al. [17] and Shawtari et al. [18], there are multiple players in public entities, including citizens, private investors and governing entities. Thus, in the public sector, governing bodies and managers, rather than being accountable to principals, are publicly accountable to, and under the scrutiny of, citizens and stakeholders. However, given that managers are mostly politically linked, and they are likely to serve their own political interests and/or the political interest of the Minister who appointed them, the principal's interest is not maximized in a situation where the agent is motivated by self-interest rather than public interest $[18,19]$. Since the separation between citizen and manager is very high, the possibility of opportunistic behavior is strong [17]. The ability of the principal to curb opportunistic behavior depends on how much information it has about the performance of the agent and the quality of the information available. In this complex situation, governance features are required to perform multiple functions: to safeguard public interest, to guarantee protection to stakeholders, and to ensure the quality of the information disclosed and compliance with the law [20].

Even though agency theory has traditionally been considered the basis for the design of governance structures, critics point out that agency theory does not completely explain various outcomes and behaviors in governance settings [21]. Thus, other theories are also being gradually applied to support, complement, or even substitute the agency theory in explaining the transparency and quality of information in the public sector. In particular, the stewardship theory has been used to complement the agency theory when discussing governance practice in public sector agencies $[13,14,22]$. Stewardship theory is seen as a particular case of the agency theory [22], in which the principal (owners) and the agents 
(managers) have similar objectives, so cooperation and collaboration is emphasized [23]. The stewardship theory proposes that the agents are motivated to act in the best interests of their principals and make decisions that are in the best interests of the overall organization in cases where different stakeholders express competing objectives [24]. Therefore, the main difference between principal-agent and principal-steward relationships is the degree of goal congruence [25]. Whereas the principal-agent relationship is characterized by low goal congruence and proneness to low trust, the principal-steward is characterized by high goal congruence and a propensity toward high trust. Stewardship theory also stresses that the concern of managers for their reputation and their intended career progression compel them to act in the interest of principals [26]. However, this theory stresses that there is some degree of pro-social motivation in any steward, which may or may not be tapped by principals, and does not necessarily imply that agents will be exclusively motivated by pro-social goals [14].

In terms of accountability, a "principal-steward" relationship may result in lower control and accountability levels from agents to principals than in a "principal-agent" relationship. When principals delegate tasks to stewards who put organizational goals above self-interest, problems related to bureaucratic drift remain minimal [25]. Thus, the type of relationship will most likely affect disclosure and accountability levels of the agencies. Increased transparency and quality of financial information is the way governing bodies and managers show public accountability and consistency with the goals and objectives of the entity, with positive consequences for the image and the reputation of the entity $[27,28]$. This may be an important way to improve the trust of citizens, other tiers of the public administrations, businesses, civil associations and other stakeholders in the public entity [29-32]. Transparency and the disclosure of reliable information to outside parties is a key aspect for public sector agencies. Under an agency theory approach, transparency and information are useful in controlling managers and making them accountable for their decisions, as well as for the overall performance of the organization. Under a stewardship theory approach, public sector agencies may gain support from the community by showing, i.e disclosing, the fulfillment of the economic and social goals of the organization, which ensures the survival of the entity, while serving as an intrinsic reward for its managers. The recent work of Torfing and Bentzen [33] supports the stewardship model approach in the management of public sector organizations because of its positive effects on employees, users and organizations, although some elements of the agency model approach are necessary for the achievement of these effects.

Before concluding this section, it is important to highlight that, in the public sector, in addition to the problem of defining the type of relationship which exists between the agents-stewards and principals, there is the problem of identifying one participant in the relationship. Whereas the identification of the agent or steward, i.e., the governing body and/or the managers, is easy, the identification of the principal is more problematic. For government agencies, on the one hand, the minister and key officials of the parent ministry can be seen as principals of the agency. On the other hand, government agencies are part the public sector and act in the interest of the citizenry, meaning that citizens are the real principals of the government agencies. In terms of accountability, Luke [34] distinguishes between "upward" and "downward" accountability. "Upward accountability" does not imply that the accountability process will be visible to outside parties and tends to involve predetermined actors/parties, potentially excluding larger constituencies, whereas downward accountability is often defined as the answerability of government to the public on its performance [35]. Analyses of the quality of financial reporting and online disclosures can also help to identify the principals and the type of relationship between them and the governing bodies, or managers, of public sector entities.

\section{Hypotheses}

Governance issues, financial results and organizational features most likely influence both the quality of the financial statements in public sector entities and their transparency 
levels. Good governance usually results in boards of directors adopting formal structures, such as a certain number of members and the presence of independent directors. The financial objective of many government entities is, usually, to have a break-even result or a small surplus/deficit, to indicate that taxes are adequately managed and, thus, managers might find incentives to use discretionary accruals to adjust financial results [36]. Organizational features affect the way entities are managed and the demands for them to be accountable. The quality of the financial statements is expected to be positively related to the transparency levels of an entity.

\subsection{Good Governance}

Good governance is represented by basic characteristics of a governing body. We focus on its size and the percentage of independent members. The effectiveness of boards to represent the different interests and views of stakeholders will depend on having a sufficient number of board members to attend to the demands of, and to provide the information required by, the stakeholders. Thus, larger governing boards might help to represent a wider group of key parties and actors interested in the activities of the entity [30]. However, larger boards may result in problems of coordination and communication and reaching consensus may be more difficult [37]. Moreover, greater stakeholder representation also increases the number of different interests represented in the board, thus hardening the stewards' ability to report satisfactory results for all the stakeholders. In addition to having more board members, one way of bringing the organization closer to its stakeholders is to appoint independent directors as representatives of those stakeholders $[27,28]$. The presence of independent directors on the boards can enhance managerial monitoring and thereby help to improve public accountability [38]. The appointment of independent directors with a good reputation may be a symbol of openness and transparency and their presence is a way of enhancing the reliability of financial information through which the public sector-controlled bodies provide financial information to different interest groups.

Empirical research has usually found a positive relationship between board characteristics and the quality of the financial statements. The meta-analysis conducted by Garcia-Meca and Sanchez-Ballesta [39] finds that firms with independent and larger boards usually have fewer discretionary accruals choices related to asset depreciation, which would show a controlling role for these mechanisms in earnings manipulation. A recent study conducted by Saona et al. [40] confirms this result in the Spanish context. However, regarding the relationship between board characteristics and online disclosures in the private sector, no significant relationship between board size and independence and the amount of information disclosed on the Internet has been found [41,42]. However, the presence of independent directors seems to be a key element for improving the information displayed on the Internet by Spanish central government agencies [43].

H1a. Good governance practices are related to a better quality of the financial statements of public sector entities.

H1b. Good governance practices are related to higher online disclosure levels of public sector entities.

\subsection{Financial Results}

In the public sector, a major result of public sector reforms in the 80s and 90s was an increased emphasis on 'management' rather than on 'administration of services'. This change entails a shift from the traditional stewardship role of accounting to more cost management and, consequently, accrual accounting [44]. The accounting system has always been closely linked to the agency problem but, in the public sector, accountability relationships between principals and agents have been shown to be more complex than in the private sector. In Spanish central government agencies, the relationship between the parent department (the responsible Minister) and the managers of the agencies can be described as an agency relationship [45]. This relationship is based on a results-oriented management model. Both Ministers (the principal) and managers (the agent) can be considered self-interested and 
maximizing agents, and they both bear and share costs. However, managers still act as stewards because their organization belongs to the public sector, and many times, their objectives are social rather than economic. Therefore, managers' decisions also put the organization, if not above, at least at the same level than their own interest.

In general, governments' financial objective is to have a small surplus to indicate that taxes have not been too high or that there is no financial burden for future generations [46,47]. Governments seek out creative solutions to balance costs with revenues in periods of fiscal restraint $[48,49]$. As in other public sector entities, agency managers may find incentives to use discretionary accruals to disguise poor financial performance, management deficiencies or funding insufficiencies in the delivery of public services, as well as to avoid increases in service costs or in deficits and to achieve forecasted financial performance measures. For Italian state-owned enterprises (SOEs), Capalvo et al. [50] provided evidence that earnings management increases with profitability. Under our multitheoretical framework, presenting better financial statements serves the particular interest of board members, because they show better performance than actual performance (agency approach), as well as benefits the whole organization because deficiencies are hidden from external control, ensuring the survival of the organization (stewardship approach).

H2a. Financial performance is related to the quality of the financial statements of public sector entities.

H2b. Financial performance is positively related to online disclosure levels of public sector entities.

\subsection{Organizational Features}

The size of the entity is usually included as a factor affecting performance and governance [51], and accountability and transparency [52]. Larger organizations are more complex, use more resources and are subject to greater visibility. Moreover, in the public sector, boards are subject to greater monitoring because public sector entities are funded by taxes and, usually they provide, or are related to, welfare services. Larger entities operate in an environment involving more complex and more time-consuming information, so board involvement is expected to increase with the size of the entity. For Eisenhardt and Schoonhoven [53], directors are less constrained by organizational systems and structures in smaller firms, may have far more discretion than their counterparts and could more easily meet their resource dependence and control targets. In addition, in a context in which agencies operate in a mix of regulatory and economic frameworks (public, nonprofit or profit), their results are affected both by their accounting framework and by managerial flexibility, because a private sector-style of management is more flexible and less bureaucratic than a public sector-style. There is evidence that earnings management decreases with firm size [50]. Therefore, organizational factors affect the behavior of board members. Following the agency theory, differences in the size, in the complexity of the organization and in information asymmetries may allow board members to benefit from these differences. In addition, the more stakeholders involved in the organization, or the greater importance of the organization for stakeholders, the greater the focus on them by the board members, which promotes a stewardship orientation of the board. It is important to point out that the governing body is the one that elaborates the financial statements and who sets the information disclosed on the internet by the organization. Following these arguments, we posit our $\mathrm{H} 3$ hypotheses:

H3a. Organizational features, size and managerial flexibility are positively related to the quality of the financial statements of public sector entities.

H3b. Organizational features, size and managerial flexibility are positively related to online disclosure levels of public sector entities.

\subsection{Relationship between Financial Reporting Quality and Transparency Levels}

Finally, a positive relationship between the quality of financial statements and the transparency of the entity is hypothesized. For Zimmerman [54], officials do not volunteer 
more information than is required or in their interest. Governing bodies, as preparers of accounting information, do not have incentives to disclose financial information that will be used by stakeholders to assess whether they have done a good job. Therefore, accounting numbers management has become a way for the members of the governing bodies and managers in the public sector to adapt accounting figures to their interests, resulting in the disclosure of lower quality financial statements. According to Zimmerman [54] and Watts and Zimmerman [55], there would be a positive relationship between the good performance of managers and the quality of the financial statements. Therefore, overall transparency, measured in the amount of information disclosed, will increase when financial statements show good performance due to the self-interest of managers in disclosing information about their good performance and their interest in showing that the organization is fulfilling its objectives.

H4. The quality of the financial statements is significantly and positively related to online disclosures about performance achievements in public sector entities.

\section{The context of the Central Government Agencies in SPAIN}

Like the UK agencies [56], Spanish agencies operate at arm's length from their parent ministries and have considerable autonomy and freedom of action. This freedom is accompanied by obligations to meet annual specific financial and operational targets agreed with the parent Minister. These targets are directed at achieving specific outcomes, financial management and the quality of service delivered. Spanish central government agencies can be allocated into five main categories according to their activities and regulation [43]. These entities can be administrative, commercial or devoted to healthcare and research activities, with the ability to use their own income in their management, which is not allowed for other public sector entities [57]. Some of these entities perform key activities in the economic, cultural and social areas. These include, among others: the Spanish Agency for International Cooperation and Development, the Spanish equivalent to the British Financial Conduct Authority (Comisión Nacional del Mercado de Valores), the equivalent to the HM Revenue and Customs in the UK (Agencia Tributaria), the Spanish Air Safety Agency, the Spanish Weather Forecast Agency, the Spanish National Library, the Institute for Cinematography and Visual Arts, the National Statistics Institute, the Nuclear Security Board, the entity that manages the Prado Museum or the several organizations in charge of the management of rivers and underground waters in Spain. Thus, these organizations play a key role in the lives of citizens. Agencies represent more than 27 percent of national civil servants and manage about one third of central government expenditure [43].

There are variations in the composition of governing bodies of Spanish central government agencies but all of them have a president and a board [43]. The board has similar responsibilities than boards of directors in the private sector or in other public sector entities. Within the board there is one person acting as a chief executive officer (CEO). CEOs are personally responsible for day-to-day operations, and they are directly accountable to the responsible minister who, in turn, is accountable to Parliament. Members of the boards are appointed by the parent ministry, other ministries, regions, municipalities, the private sector and trade unions. Garcia-Juanatey et al. [57] argue that the introduction of the public agencies in Spain has improved transparency in the Spanish Public sector, promoting an awareness by civil servants of the importance of rendering accounts of their activities. However, other entities linked to the Spanish public sector do not show good disclosure levels. The results of Royo et al. [35] show that Spanish SOEs do not consider websites a key tool to communicate with their stakeholders. These authors argue that the online disclosures of these entities are mainly focused on financial issues, and most SOEs are silent about their policies, objectives and corporate governance structures, which suggests that they are accountable to shareholders and not to the public in general. 


\section{Research Design and Methodology \\ 5.1. Sample and Data}

The initial sample consists of the 196 agencies controlled by the Spanish central government. Within the term 'agencies' we include executive agencies, administrative agencies, consortiums, business-like agencies and other autonomous entities, listed on the Inventario de Entes del Sector Público Estatal (https:/ / www.igae.pap.hacienda.gob.es/sitios/ igae/es-ES/BasesDatos/ClnInvespe/Paginas/invespe.aspx) at 31st December 2015. For all these entities, we conducted a data search considering three aspects: the website available, financial statements available and information about their governing body/boards of directors. Of the agencies, 168 had a website. We found complete annual accounts allowing us to conduct analyses about their quality for 107 agencies. Financial data for each agency had been collected from financial statements for the year ending on 31st of December of 2015, published either on the website of the Internal Audit Office, the IGAE or in the Spanish official gazette (BOE). Information about the boards of directors was found for 141 agencies. Once the information about these three aspects is combined, the number of agencies available for the analyses is 77 , i.e., almost $40 \%$ of the total population. Therefore, the final sample of 77 agencies has been determined by the availability of information for the three aspects explained above. Implications about the disclosure and availability of information from Spanish agencies are presented in the discussion section. The agencies in the final sample obtain, on average, higher scores on online disclosure than the sample of the 168 agencies with websites.

\subsection{Structural Equation Model Using PLS-SEM}

One of the main problems in the analysis of the transparency and accountability of public sector entities is the difficulty of determining the variables that capture these elusive concepts. Therefore, the choice of a statistical tool that fits the characteristics of these entities and their outputs and outcomes is crucial. In this setting, we considered the Structural Equation Model Partial Least Square (PLS-SEM) approach (SmartPLS 2.0 software) to be the appropriate technique for the analysis. Three main advantages of this technique can be highlighted. First, it uses constructs as variables. Constructs, also called latent variables, are made up of several items or indicators to better capture the characteristics of the complex 'reality' being studied, strengthening the results and their interpretation. Second, it allows the inclusion of more than one 'dependent variable', so the influence of one variable (construct) on two or more dependent variables can be measured at the same time. It also allows the study of interactions between variables; that is, some variables can be both a dependent variable and an independent variable. So, the structural model allows researchers to study complex relationships between variables with different effects. Third, while other approaches to SEM, such as covariance-based methods, have strong sample-size requirements, PLS-SEM restrictions are generally smaller. A sample of 77 cases, like ours, can be considered adequate considering the total number of entities in the population (196).

\subsection{Dependent Variables}

With PLS-SEM, all dependent variables are constructs, so they better capture the quality of the financial statements and the transparency of the Spanish central government agencies.

\subsubsection{Financial Quality Score}

Numerous studies use measures of discretionary accruals as surrogates for earning quality [58-61]. The flexibility afforded through accrual accounting makes the accrual component of earnings less reliable than the cash flow component and is, therefore, a potentially useful measure for examining the quality of financial reports. Discretionary Accruals (DA) are accounting accruals that differ from accruals that are expected according to the entity's activity. As earnings management can involve either income-increasing or 
income-decreasing accruals, we use the absolute value of discretionary accruals as a proxy for earnings quality [62].

In order to better capture the quality of the financial statements, we created a construct, Fin_(un)quality, with the absolute value of DA estimated cross-sectionally from three models frequently used in the literature: abDA1 (Kasznik), abDA2 (Jones) and abDA3 (modified Jones) (see Appendix A). The variables are scaled by lagged assets to mitigate the effect of heteroscedasticity. This way, the construct shows deviations from the real result, regardless of the sign of the DA. We estimated these equations for the 107 entities with available financial data. (We used all agencies with available financial data to estimate these models regardless of whether they have or do not have data on corporate governance in order to obtain more robust estimations of DA. The modified Jones model requires information not available for three entities, which reduced the entities for which estimations were conducted with this model to 104 . We also conduct a correlation analysis to observe the relationship between the budgetary result and the estimated discretionary accruals, to better explain and interpret the relationship. For this analysis, discretionary accruals are included with their sign.

\subsubsection{Transparency Indexes}

To assess the transparency of the Spanish agencies, we carried out a content analysis of their websites, based on the Spanish legal framework for freedom of information, between July 2016 and February 2017. This is an adequate period in terms of the analysis of the relationship between financial quality and transparency for the annual financial statements of 2015. In the Spanish public sector, the preparation of the financial statements takes longer than in the private sector and the financial statements approved by the management team are usually available during the last quarter of the following year. In this way, congruency between the analysis of the financial statements and transparency is ensured.

In our analysis of the websites, we gave each item the value ' 1 ' if it appears in the website and ' 0 ' if not. This methodology has been applied by most academic papers for gauging the informational contents of the websites. We depart from the checklist developed by Pina and Torres [43]. From that list, we used for our analyses 76 items and allocated them into six categories. The categories in our study are slightly different than the ones used by these authors. First, the financial dimension used by these authors is divided into two categories in order to better capture the type of information the entities disclosed about their performance. Second, during the stage of assessing the measurement model, some items were removed in order to achieve adequate measurement scales (as explained below in the results section). The six categories used for our study are: (1) Financial information, FI, (six items), focused on financial information and reports and (2) Performance information, focused on additional non-financial information about performance, PI, (four items), assess the degree of transparency with regard to the use of financial resources, financial position, performance and audit reports. Citizen dialogue, CD, (twelve items), includes information about interaction and participation tools with citizens. Institutional information, II, (twentyfive items), describes the degree of transparency with regard to the government's mission and operations, its institutional activities and other information. Accessibility, AC, (five items) focuses on the development of tools for making the website contents accessible to disabled people and the public at large. The Usability category, US, (24 items) refers to the ease with which users can access information and navigate the Web portal as a function of how accessible and user-friendly the specific contents are. The score of each category is the result of adding up the ' $1 \mathrm{~s}$ ' obtained in the content analysis.

We allocated the six categories into three constructs, each made up of two of the categories, so transparency can be analyzed considering three main dimensions, namely, performance transparency, citizen transparency and transparency easiness. Performance transparency (TR_perform) is made up of FI and PI and it assesses the transparency of the entities with respect to their financial performance and service quality. Citizen transparency (TR_citizen) is made up of CD and II, and it assesses the information provided to the 
citizenry about the institution and the communication channels with users and citizens. Transparency easiness (TR_easiness) is made up of AC and US and it assesses the quality of the websites and the features that enable users to navigate easily. Serrano-Cinca et al. [63] use a similar methodological approach, PLS-SEM and website content analysis, to create constructs to determine the factors that explain the financial transparency of banks on the Internet. As explained, we included a correlation analysis to observe the relationship between the budgetary result and the estimated discretionary accruals, to better explain it and interpret it.

\subsection{Independent Variables}

We include all the independent variables of the model, presented in this section, as single indicators. The use of single-item indicators (or constructs) is not restricted in PLS-SEM [64]. This approach allows us to identify better the governance, financial and organizational factors that are related to financial quality and transparency. Our model has six independent variables, representing three features that can affect the quality of the financial reporting and online disclosure levels, namely the governing body, financial results and organizational characteristics. There are two independent variables for each of these three features.

\subsubsection{Governing Body Variables}

We included in our model two features of the governing body to study how it is related to both financial quality and transparency, namely BDcontrol and BDsize. BDcontrol is a variable that captures the percentage of 'non-independent' board members over the total number of members. Non-independent directors are those appointed by the parent ministry and/or by other central government ministries. Non-independent directors represent the central government control on the agency. We consider independent directors to be those who come from other tiers of the public administration, such as regional and local governments, and directors who do come from trade unions, NGOs, civil associations and industries. Therefore, independent directors represent different stakeholder interests and may seek to influence the organization's response to their demands [65]. Independent directors promote global relationships and board independence because people with different backgrounds provide new insights and perspectives [66], increase discussion, promote the exchange of ideas [67] and improve organizational value [68]. Thus, in fact, $B D c o n t r o l$ represents the opposite of board independence.

$B D s i z e$ captures the number of board members. This board characteristic is frequently included in the study of the influence of the boards on the performance and transparency of economic entities. The number of directors could condition the activities of monitoring and control of the accountability process of the entity, even though the empirical results are not conclusive.

\subsubsection{Financial Variables}

Two variables, namely RSbudget and Surplus, aim to capture the information of the net borrowing/net lending figure used by Eurostat to monitor the fulfillment of the deficit limits established for the Eurozone countries. Net borrowing/net lending is a concept included in the European System of Accounts under the accrual basis of accounting. As the national budgets of Eurozone countries apply the modified accrual or cash basis of accounting, Eurostat makes a number of adjustments to the non-financial items of the budgets of different countries. Therefore, the budgetary result represents the basis on which Eurostat makes the adjustments to the national budgets. Even though the surplus is elaborated on an accrual basis, it is not equal to the net borrowing/net lending variable because not all items included in the surplus are included in the net borrowing/net lending variable (for instance, amortizations, depreciations and financial items are not included) and tax revenues are accounted for under the cash basis and not the accrual basis. Therefore, the budgetary result and the surplus represent the range of values captured by the net 
borrowing/net lending figure. Net borrowing/net lending cannot directly be included in the model because countries disclose the information for the whole central government and not for each agency under its control (agencies manage around 30\% of the central government budget). In our analysis, we included two variables that capture the financial performance of the Spanish agencies. The first is RSbudget, which captures the absolute value of the budgetary result of the agencies. For the entities that do not elaborate a budgetary statement, we used as a proxy the absolute value of the financial result in its natural $\log$ form. The second variable that captures the financial performance of the agencies is a dummy variable, Surplus, which takes ' 1 ' when there is a financial surplus at the end of the financial year, and ' 0 ' otherwise.

\subsubsection{Organizational Variables}

We selected two organizational variables to study their relationship with financial quality and transparency: the size of the organization (Size) and the accounting system used, that is, whether it uses private or public sector accounting standards (IFRS). Size captures the amount of resources used by the entity to provide goods and/or services. We measure it as the total assets reported in the balance sheet and it is introduced into the model in its natural $\log$ form. IFRS is a dummy variable that takes value ' 1 ' when the entity elaborates its financial statements according to private sector GAAP, mainly based on the International Financial Reporting Standards (IFRS), and ' 0 ' when it applies public sector accounting standards, mainly based on the International Public Sector Accounting Standards (IPSAS). This variable reflects the accounting framework of the entity and captures differences in managerial flexibility.

\subsection{Model}

Figure 1 is a graphic representation of the variables and constructs in the model and the relationships, and hypotheses, to be tested. Ellipses represent constructs made up of several items. Rectangles represent constructs with only one variable. Our model tests the relationship between the governance, financial and organizational variables and both financial quality and transparency, as well as the relationship between financial quality and transparency in the performance dimension. First, the dependent variables, those that capture the financial quality and the transparency of the entities studied, are constructs because they are elusive concepts and our design allows a better representation. Second, we included the independent variables as single-item variables because they are specific aspects of the entities and allow an easier and better interpretation. For each feature of the entities analyzed (governance, financial and organizational aspects) we included two variables so the model does not give more importance to one dimension than to the others. Third, the model also studies the relationship between financial quality and financial transparency, because accountability is not only about transparency, but also about reporting useful and reliable information.

Financial quality and the budgetary result are included in their absolute values, so it is not possible to observe the relationship of their signs. As explained, we included a correlation analysis to observe the relationship between the budgetary result and the estimated discretionary accruals (DA). We allocated entities into two groups. One is made up of entities with a financial surplus for the year and the other consists of the rest of the entities, that is, those that present a deficit or zero in their financial surplus/deficit for the year. Then, we carried out a Spearman correlation analysis between the absolute value of the budgetary result, in the natural form, and the three estimated discretionary accruals maintaining the sign of the estimation (DA). The correlation between these aspects allowed us to observe the effect of the DA on the financial performance, that is, whether DA are used to 'move' the financial result towards break-even or not. It is worth recalling that, for those entities that do not report budgetary information, the financial result included is the one reported in their income statement. 


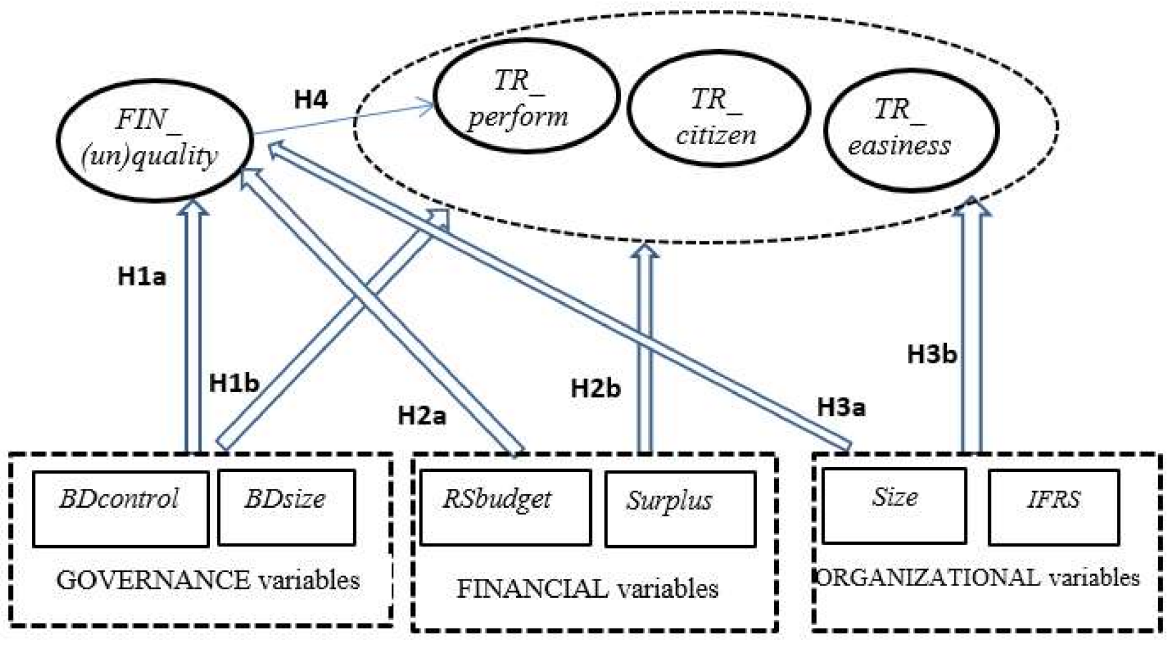

Figure 1. Variables, constructs and relationships tested in the model Circles represent constructs, rectangles represent single item variables.

\section{Results}

Table 1 shows the descriptive statistics of the variables included in the analyses. The mean of the different estimations of the discretionary accruals range from 0.040 and 0.044 , which are lower than those reported in previous literature. For example, in the private sector, some results are: 0.077 [58], 0.08 [59] and 0.066 [69]. In British local governments, Arcas and Martí [36] find 0.081. Spanish agencies show, on average, low scores in transparency. For the financial and non-financial information, the percentage of items present on the website is, on average, $46.5 \%$. In terms of information for citizens, scores are higher, with an average presence of $47.4 \%$ of the items for citizen dialogue and $69.2 \%$ of the items for institutional information. The ease of use of the websites presents good scores for accessibility, an average of $62.4 \%$, while, on average, scores are low for usability.

Table 1. Descriptive statistics of the items included in the analyses $(\mathrm{N}=77)$.

\begin{tabular}{ccccc}
\hline Variables & Mean & Min & Max & Std. Dev. \\
\hline AbDA1 & 0.040 & 0 & 0.232 & 0.047 \\
AbDA2 & 0.044 & 0 & 0.203 & 0.050 \\
AbDA3 & 0.043 & 0 & 0.202 & 0.050 \\
FI & 2.792 & 0 & 6.000 & 1.341 \\
PI & 1.857 & 0 & 3.000 & 0.899 \\
CD & 5.688 & 1.000 & 9.000 & 1.995 \\
II & 17.286 & 4.000 & 24.000 & 4.151 \\
AC & 3.117 & 1.000 & 5.000 & 1.367 \\
US & 9.494 & 1.000 & 15.000 & 2.511 \\
BDsize & 18.922 & 5.000 & 61.000 & 10.799 \\
BDcontrol & 0.530 & 0 & 1.000 & 0.273 \\
RSbudget $(€ 000)$ & 44,746 & 1 & $2,586,945$ & 294,151 \\
IFRS * & $25 *$ & & $1,907,121$ \\
Size (€000) & 739,418 & & & \\
Surplus * & $48^{*}$ & 1712 & &
\end{tabular}

Boards (BDsize) are quite large, with an average size of almost 19 members and a presence of $53 \%$ non-independent directors (BDcontrol), which means that they are a majority on the board which allows them to control the entities. The budgetary result (RSbudget) of the entities included in the sample is, on average, more than $€ 44$ million, and 48 of them present a positive financial result for the year (Surplus). The entities analyzed manage, on average, assets of almost (Size) $€ 740$ million, and 25 of them apply GAAP following private sector accounting standards (IFRS). 
PLS-SEM analysis must be developed in two stages: the measurement model analysis and the structural model analysis. The measurement model assessment involves the examination of the adequacy of the measurement scales. The structural model focuses on testing the causal paths between the constructs that compose the theoretical model. As the sample is made up of the agencies with complete data, there are no missing values. This explains the analyses carried out for the two stages and the results obtained.

\subsection{Analysis of the Measurement Model}

We estimated the measurement model with PLS-SEM in order to analyze its internal consistency. This process essentially involves three stages [70]. The results of the estimation of our measurement model are presented in Table 2. First, the unidimensionality of the indicators is evaluated using their factor loadings $(\lambda)$. This permits an evaluation of whether or not each indicator of the construct is highly correlated with the characteristic that it intends to capture. All $\lambda$ exceed the threshold of 0.7. Second, reliability is explored using the CRI value to measure composite reliability and Cronbach's Alpha for simple reliability. Reliability indicates whether or not the set of variables are consistent in what they intend to measure. The CRI values exceed the critical threshold of $0.7-0.8$ [71] for all variables. For the Cronbach's Alpha, 0.7 is usually considered the critical threshold. This threshold is exceeded for FIN_(un)quality and TR_citizen, is close to that threshold for TR_perform (0.67) and is 0.57 for TR_easiness. Academic papers such as Malloy and Agarwall [72] present CRI values around 0.6, so all our values are acceptable. Hair et al. [64], using the work of Bagozzi and Yi [73] as their reference, indicate that the assessment of the internal reliability should be based on the CRI value and the use of Cronbach's Alpha should be avoided. In any case, the validity of the values must take into account the meaning of the items and whether they are capturing similar aspects. Third, validity is assessed by using convergent validity and discriminant validity. Convergent validity is analyzed through the average variance extracted (AVE) values and evaluates the degree to which the indicators represent the construct. Table 2 shows that all the AVE values are above 0.5 , which guarantees convergent validity [73]. Discriminant validity indicates whether each construct in the model is significantly different from the others. The most accepted method for PLS-SEM is the comparison of the square root of the AVE values and the correlation between variables. Table 3 presents the square root of each construct's AVE values on the diagonal and the estimated correlations for each pair of constructs off the diagonal. Single-item variables, that is, our independent variables, take the value ' 1 ' for all the measures: Cross-loadings, Alpha, CRI and AVE. Therefore, this information is not presented in Table 2.

Table 2. Measurement model.

\begin{tabular}{|c|c|c|c|c|c|}
\hline Construct & Indicator & $\begin{array}{l}\text { Factors } \\
\text { Loadings } \\
(\lambda)\end{array}$ & $\begin{array}{c}\text { Cronbach's } \\
\text { Alpha }\end{array}$ & $\begin{array}{c}\text { Composite } \\
\text { Reliability } \\
\text { Index (CRI) }\end{array}$ & $\begin{array}{c}\text { Average } \\
\text { Variance } \\
\text { Extracted } \\
\text { (AVE) }\end{array}$ \\
\hline FIN_(un)quality & $\begin{array}{l}\text { AbDA1 } \\
\text { AbDA2 } \\
\text { AbDA3 }\end{array}$ & $\begin{array}{l}0.9743 \\
0.9831 \\
0.9966\end{array}$ & 0.9843 & 0.9896 & 0.9696 \\
\hline TR_perform & $\begin{array}{l}\text { FI } \\
\text { PI }\end{array}$ & $\begin{array}{l}0.8189 \\
0.9059\end{array}$ & 0.6657 & 0.8540 & 0.7457 \\
\hline TR_citizen & $\begin{array}{c}\text { CD } \\
\text { II }\end{array}$ & $\begin{array}{l}0.8590 \\
0.9096\end{array}$ & 0.7249 & 0.8779 & 0.7826 \\
\hline TR_easiness & $\begin{array}{l}\text { AC } \\
\text { US }\end{array}$ & $\begin{array}{l}0.8344 \\
0.8394\end{array}$ & 0.5723 & 0.8238 & 0.7004 \\
\hline
\end{tabular}

Note: Information presented only for the constructs made up of two or more items. 
Table 3. Discriminant validity.

\begin{tabular}{|c|c|c|c|c|c|c|c|c|c|c|}
\hline & BDcontrol & BDsize & FIN_(un)Quality & TR_Citizen & TR_Perform & $\begin{array}{c}\text { TR_- } \\
\text { Easiness }\end{array}$ & IFRS & RSbudget & Size & Surplus \\
\hline BDcontrol & 1 & & & & & & & & & \\
\hline BDsize & -0.428 & 1 & & & & & & & & \\
\hline FIN_(un)quality & 0.329 & 0.006 & 0.985 & & & & & & & \\
\hline TR_citizen & -0.030 & 0.116 & -0.079 & 0.885 & & & & & & \\
\hline TR_perform & -0.128 & 0.019 & -0.241 & 0.630 & 0.864 & & & & & \\
\hline TR_easiness & 0.029 & 0.233 & 0.059 & 0.587 & 0.366 & 0.837 & & & & \\
\hline IFRS & -0.251 & -0.037 & -0.213 & 0.042 & 0.157 & 0.065 & 1 & & & \\
\hline RSbudget & 0.175 & -0.056 & 0.375 & 0.027 & 0.026 & 0.154 & 0.179 & 1 & & \\
\hline Size & -0.110 & 0.270 & -0.119 & 0.334 & 0.314 & 0.434 & 0.486 & 0.295 & 1 & \\
\hline Surplus & -0.223 & 0.040 & 0.043 & 0.116 & 0.244 & -0.178 & 0.196 & 0.082 & -0.001 & 1 \\
\hline
\end{tabular}

\subsection{Analysis of the Structural Model}

Having confirmed the adequacy of the measurement scales for the constructs included in the model, the structural model is estimated. To assess the significance of the path coefficients, we use a bootstrapping procedure with 5000 subsamples. The results of the structural model that tests the relationships presented in Figure 1 are shown in Figure 2 and in Table 4.

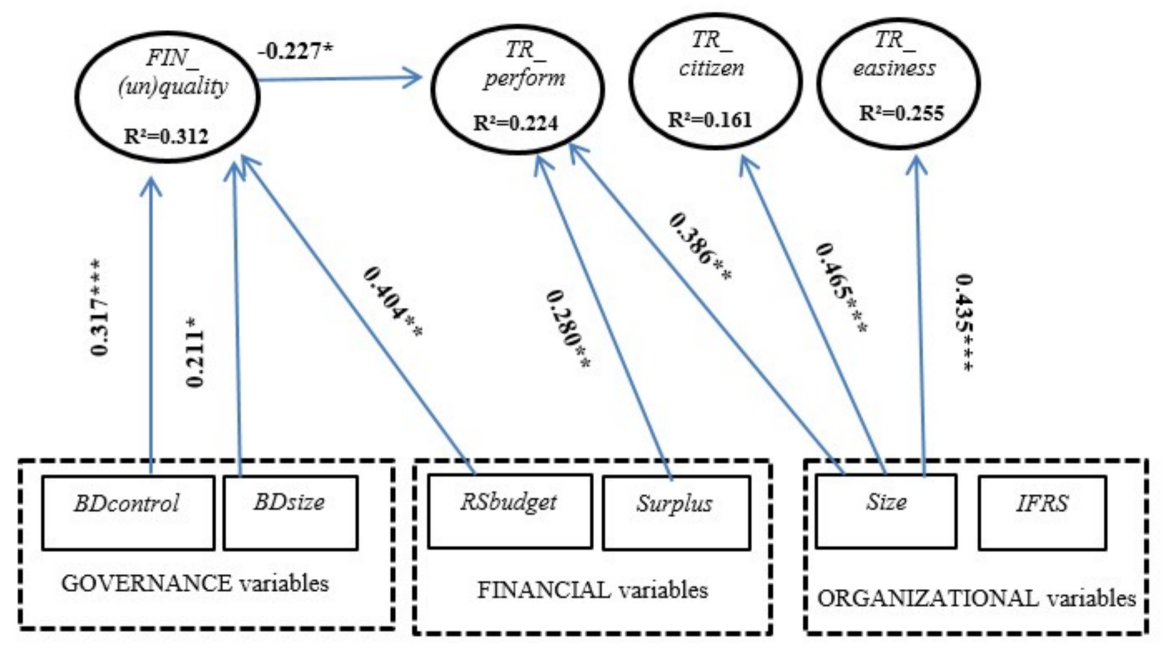

Figure 2. Graphical representation of the results of the structural model (only significant relationships shown). Note: ${ }^{* * *}$ significant at the 0.01 level; ${ }^{* *}$ significant at the 0.05 level; ${ }^{*}$ significant at the 0.1 level.

Table 4. Results of the structural model.

\begin{tabular}{lcc}
\hline & $\boldsymbol{\beta}$ & $\boldsymbol{t}$-Value \\
\hline BDcontrol $\rightarrow$ FIN_(un)quality & 0.317 & $2.656^{* * *}$ \\
BDcontrol $\rightarrow$ TR_perform & -0.035 & 0.243 \\
BDcontrol $\rightarrow$ TR_citizen & 0.017 & 0.123 \\
BDcontrol -> TR_easiness & 0.074 & 0.475 \\
BDsize $\rightarrow$ FIN_(un)quality & 0.211 & $1.686^{*}$ \\
BDsize $\rightarrow$ TR_perform & -0.116 & 0.916 \\
BDsize $\rightarrow$ TR_citizen & -0.021 & 0.164 \\
BDsize $\rightarrow$ TR_easiness & 0.152 & 1.061 \\
RSbudget $\rightarrow$ FIN_(un)quality & 0.404 & $2.090^{* *}$ \\
RSbudget $\rightarrow$ TR_perform & -0.000 & 0.003 \\
RSbudget $\rightarrow>$ TR_citizen & -0.093 & 0.867 \\
RSbudget $\rightarrow>$ TR_easiness & 0.052 & 0.467 \\
\hline
\end{tabular}


Table 4. Cont.

\begin{tabular}{lcc}
\hline & $\beta$ & $t$-Value \\
Surplus -> FIN_(un)quality & 0.095 & 0.934 \\
Surplus -> TR_perform & 0.280 & $2.497^{* *}$ \\
Surplus -> TR_citizen & 0.167 & 1.286 \\
Surplus -> TR_easiness & -0.152 & 1.270 \\
Size -> FIN_(un)quality & -0.203 & 1.444 \\
Size $\rightarrow$ TR_perform & 0.386 & $2.294^{* *}$ \\
Size-> TR_citizen & 0.465 & $2.818^{* * *}$ \\
Size $\rightarrow$ TR_easiness & 0.435 & $2.525^{* *}$ \\
IFRS $\rightarrow$ FIN_(un)quality & -0.118 & 1.341 \\
IFRS $\rightarrow$ TR_perform & -0.147 & 1.106 \\
IFRS $\rightarrow>$ TR_citizen & -0.196 & 1.414 \\
IFRS $\rightarrow$ TR_usab & -0.102 & 0.745 \\
FIN_(un)quality -> & -0.227 & $1.727^{*}$ \\
TR_perform & &
\end{tabular}

$\mathbf{R}^{\mathbf{2}}$ for FIN_(un)quality: $\mathbf{0 . 3 1 1}$

$\mathbf{R}^{2}$ for TR_perform: $\mathbf{0 . 2 2 4}$

$\mathbf{R}^{2}$ for TR_citizen: $\mathbf{0 . 1 6 1}$

$\mathbf{R}^{2}$ for TR_easiness: $\mathbf{0 . 2 5 5}$

Note: ${ }^{* * *}$ significant at the 0.01 level; ${ }^{* *}$ significant at the 0.05 level; ${ }^{*}$ significant at the 0.1 level.

The structural model is examined by observing the $\mathrm{R} 2$ values of the dependent variables. The model explains $31 \%$ of the variance in the construct reflecting the (un)quality of the financial statements, $22 \%$ of performance transparency, $17 \%$ of transparency and communication with the citizenry and $26 \%$ of ease of use. PLS-SEM does not provide a global indicator of the goodness of fit of the whole model. The two governance factors of our model, BDcontrol, at the $1 \%$ level, and BDsize, at the $10 \%$ level, are significantly and positively related to a worse financial quality (FIN_(un)quality), and their relationship with the three transparency (TR_perform, TR_citizen and TR_easiness) dimensions is not significant. That is, the larger the board and the higher the presence of non-independent directors, which reflects a higher level of control from the parent Ministry, the greater the discretionary accruals estimated in their financial statements. Therefore, for those entities that do not follow good governance practices, the quality of the financial information is worse; that is, H1a is supported. H1b is not supported because there is no significant relationship between board characteristics and transparency. As discussed below, this might be due to a lower concern with downward accountability (to citizens and the public) than with upward accountability (to authorities and the government).

For the financial variables, the budgetary result is positive and significantly related to FIN_(un)quality. That is, a larger budgetary result is related to a worse financial quality, so $\mathrm{H} 2 \mathrm{a}$ is supported. Having a surplus for the year results in a higher transparency of organizational performance (TR_perform). The financial variables do not show a significant relationship with the other two transparency dimensions, TR_citizen and TR_easiness. Therefore, $\mathrm{H} 2 \mathrm{~b}$ is partially supported. As explained in Section 5.3, because discretionary accruals and budgetary results are included in their absolute values, a correlation analysis has been carried out distinguishing between entities that report a financial surplus for the year and those that do not. This analysis allows us to observe the 'intention' of managers when using discretionary accruals. For these analyses, discretionary accruals are presented in their natural value. Results are presented in Table 5.

The results of Table 5 suggest that, for entities that report surpluses, there is a negative correlation between discretionary accruals and the budgetary result. The correlation is not significant but suggests an interesting relationship. Entities with a higher budgetary result seem to use discretionary accruals to reduce their financial results in order to show a figure closer to the break-even and, in this way, compensate a high budgetary result. For entities with a deficit, the correlation is similar, but the interpretation is that the effect pretends to get closer to break-even by showing a better result by reducing this deficit. 
Table 5. Measurement model.

\begin{tabular}{ccccc}
\hline & & DA1 & DA2 & DA3 \\
\hline $\mid$ RSbudget $\mid$ & Coef & -0.040 & -0.028 & -0.020 \\
$($ Surplus $=1)(\mathrm{n}=48)$ & Sig. & 0.789 & 0.850 & 0.894 \\
\hline $\mid$ RSbudget $\mid$ & Coef & -0.018 & -0.103 & -0.102 \\
$($ Surplus $=0)(\mathrm{n}=29)$ & Sig & 0.927 & 0.595 & 0.599 \\
\hline
\end{tabular}

For the organizational factors studied, the size of the entity is negatively related to the level of financial (un)quality, that is, the larger the entity the better the quality of the financial statements, but this relationship is not statistically significant. The type of accounting regime, which, as explained, also captures different administrative processes, is not significantly related either to the quality of the financial statements or to the transparency of the entities analyzed (H3a not supported). However, the size of the entity is significantly related to the three transparency dimensions studied (TR_perform, TR_citizen and TR_easiness), so hypothesis H3b is supported.

Finally, our results indicate that the quality of the financial statements and the disclosure of financial and non-financial information, captured by the construct TR_perform, are related dimensions. Financial accountability is not only about presenting a greater quantity or a better quality of information, but of presenting both characteristics together. The significant and negative relationship between the level of discretionary accruals and TR_perform indicates that those who 'manipulate' more their financial statements disclose less information. This result supports our hypothesis $\mathrm{H} 4$, that is, accountability is a multidimensional concept and that its dimensions are interrelated.

\section{Discussion}

The sustainability of some public sector entities is in the agenda of many governments. Sustainability from a broad perspective, that is, considering the economic, environmental and social dimensions as well as legitimacy to perform activities that pursue to achieve developments in those dimensions. Thus, one element for entities to survive is to achieve those goals while following good governance practices, which require performing and conforming with those practices. In particular, the accountability of the governing bodies of public sector entities must be real throughout the disclosure of more and better, more reliable, information.

Academic research has identified the size and the independence of the governing body as two key features influencing accountability and information disclosure. Thus, they have been included in empirical models designed to test the influence of the board of directors on the accountability and performance of public and private entities. Our results indicate that the prevalence of non-independent directors and, to a lesser extent, larger boards, are related to higher discretionary accruals; that is, they have a negative effect on the quality of financial information. This shows the benefits of having independent directors on the governing body to monitor the quality of the financial reports and, thus, to hold managers accountable. Although the size of the governing body increases diversity, because large boards can more easily include the participation of different stakeholders, larger boards have some inconveniences such as the costs of poorer communication and decision-making associated with larger groups, as well as a greater likelihood of control of the board by the CEO. Agency and stewardship theories highlight the importance of independent directors as representatives of stakeholders, thus indirectly, the size of the board, because it makes it easier to introduce them in boards. However, our results support a negative relationship between larger boards and the quality of the financial statements. This shows that size does not guarantee either greater stakeholder representation or a higher percentage of independent directors. The quality of financial information is significantly related to the political and background variety provided by the percentage of independent directors. Independent directors in public entities are representative of other public administrations 
governed, sometimes by different political parties and public and private sector stakeholders related to the activities and/or goals of the agency. For CIPFA [6] one of the major considerations of the Cadbury Committee was to examine the issue of the balance of power within entities. Independent members not involved in the management of the entity bring other perspectives to strategy development and decision-making and hold the executive accountable for its performance [74]. Therefore, the quality of the financial reports is enhanced by the members not appointed by the central government.

The pressure of Eurozone requirements has been introduced into the model through the budgetary and financial results of the agencies. Agencies might be motivated to manage net operating cost numbers for several reasons [10]. One is to signal that they meet their objectives and provide services at a reasonable cost. Another is that they need to justify funding from Parliament. Budgetary results are calculated on a modified cash basis of accounting and financial results on a full accrual basis. Both results establish the ends of the range through which the net borrowing/net lending required by the European System of Accounts (ESA) moves. Public managers focus especially on budget figures and, at the end of the period, they use the adjustments of budgetary figures required by the ESA to calculate the deficit and the net borrowing/net lending on an accrual basis to smooth their financial results. The sign of the correlation analysis provides indication that entities with a positive result use discretionary accruals to reduce their reported financial results in order to show a figure closer to the break-even established for Spain by the Eurostat for the fulfilment of the limits of deficit and debt and, in this way, compensate a high budgetary result. For entities with a deficit, the correlation is similar but the interpretation is that the effect is to get closer to break-even by showing a better financial result by reducing this deficit. These results are similar to those found by Pina et al. [10] for UK executive agencies which show that managers adjusted reported financial results in order to keep the net operating cost of agencies around zero. The budgetary result is the data used by Eurostat to estimate the net borrowing/net lending of agencies in order to assess the fulfilment of the deficit and debt limits established for each Eurozone country. The financial result represents the financial performance measured under the accrual basis which is a figure closer to the net borrowing/net lending of the European System of Accounts than the budgetary result. Under this system, good budgetary results are not necessarily seen as reflecting good managerial performance. Our analysis suggests that, with good budgetary results, discretionary accruals are used to smooth financial results in order to bring them closer to the Eurozone deficit and debt limits.

Our analysis does not find a significant relationship between the governance features of agencies and their transparency. This may be because agencies are free to design their websites and select the information disclosed, and all transparency indices are mostly based on the information published on the Internet. Our analysis confirms that the financial performance is related to the transparency levels of the Spanish agencies. In particular, entities with a positive financial result (surplus) for the year have a significantly higher level of transparency in the performance dimension than those that have a deficit. However, having a surplus for the year does not affect the other transparency dimensions. Similarly, a better budgetary result does not affect transparency levels. This result is consistent with the idea that those who achieve a positive financial result are more willing to disclose information about the performance of the entity, but not necessarily about other aspects, supporting the agency theory argument of possible opportunistic behavior by managers.

Our results indicate that organizational features influence transparency levels with a significant relationship between the size of the entity and the three dimensions of transparency based on Spanish freedom of information legislation. The size of the entities affects their visibility, large entities being under a narrower scrutiny from stakeholders than small ones. These results are hypothesized by agency and stewardship theories, which support the idea that large entities are exposed to closer monitoring by institutions and stakeholders and, therefore, they are more interested in gaining legitimacy. However, our results are valid for the agencies of our sample. For a significant number of entities it has not been 
possible to obtain the information needed for our analyses. It seems, in line with the results of Royo et al. [35] that some public sector entities do not feel real urgency to report to the citizenry. Agencies most likely perceive their parent ministry and the organizations represented on their governing body as their principals. The composition of the governing body does not seem to be the factor that affects online disclosure.

Our analyses provide support to the idea that accountability is a concept with interrelated dimensions. In particular, the quality of the financial statements and the amount of information provided about the performance of the entity are positively related. Those who elaborate 'better' financial statements are 'more willing' to disclose information about the results and performance of the entity. These results are consistent with the world-wide tendency to expand the content of financial reports with non-financial information. The European Commission has recently published guidelines for big companies to report nonfinancial information based on the international integrated reporting framework in order to improve their accountability and transparency. Public accountability implies making the accountability process transparent to outside parties. Agency theory sees increased transparency as the way that managers show public accountability and consistency with the goals and objectives of the entity, with positive consequences for the image and institutional reputation of the entity among stakeholders. Under the stewardship theory, increased transparency can be seen as an indicator of public accountability and commitment with the users of the service. This may be an important way of improving the trust of citizens, taxpayers, other tiers of the public administrations, businesses, civil associations and other stakeholders in the public entity. This greater trust will most likely result in the sustainability of the services provided by the organization because the citizenry is more aware of their importance. However, our results suggest that Spanish central government agencies need to improve their accountability towards citizens. In particular, they have to make important efforts to improve their transparency, online disclosure, levels. They should disclose information to the citizenry through their websites, which is now a common information tool used by citizens. The information disclosed should include performance information as well as information about those who manage the entity. As enforcement of transparency-related legislation is scarce in Spain, legal, compulsory measures should ensure disclosure requirements on the Internet.

Finally, we must acknowledge some limitations of this study. One limitation of this work is that it focuses on Spanish central government agencies and the results may vary if the study is applied to public sector entities with a different degree of autonomy or controlled by regional governments, or in different countries. Second, our analyses are focused on one year and only on those entities for which complete data was available. The growing introduction and use of Web 2.0 and social media tools provide arguments for new studies to observe their influence on the accountability of public sector entities. Future research should also focus on other European agencies in order to compare results.

\section{Conclusions}

The sustainability of some public sector entities is a key concern for many developed governments. The public sector is under the scrutiny of the citizens who demand better service quality, value for money and greater accountability. The agency and stewardship theories are useful for explaining the complex and open-ended relationships between governors, managers and citizens/stakeholders in the autonomous entities of the public sector. This study is focused on the accountability dimension of the public sector in terms of the quantity and quality of online disclosures. The composition of the boards of directors is revealed in this study as key in explaining the level of quality of the financial reports of the agencies studied. A lower presence of independent directors, who usually represent a variety of stakeholders not appointed by the central government, is an explanatory factor of a lower quality of the financial reports. Independent directors are typically representatives of other tiers of the public administration, which may be governed by different political parties, NGOs or business organizations related to the activities and/or goals of the agency. 
Therefore, independent directors will be more likely to enhance the reliability of financial reports used to hold these entities accountable.

Our findings show that the quality of the financial information is also affected by the pressure that the requirements (deficit limits) of Eurostat put on public entities, which leads to the use of smoothing practices. These practices are limited by the independent board members not involved in the direct management of the public entity, who are interested in public accountability aspects.

Our analysis has found a significant relationship between transparency and the size of the agency. The size of the agencies affects their visibility and public accountability, large entities being under narrower stakeholder scrutiny than small ones. Public accountability implies making the accountability process transparent to outside parties. Agency and stewardship theories support the idea that large entities are subject to closer monitoring by institutions and stakeholders so they are more interested in gaining legitimacy. The results also indicate that public accountability is concerned with both the quality of the financial statements and the disclosure of financial and non-financial information. These results are consistent with the world-wide tendency to expand the content of financial reports, introducing non-financial information through Integrated Reporting. Adequate financial and non-financial disclosures are needed for the sustainability of entities across sectors.

Author Contributions: All authors participated in all aspects of this study. All authors have read and agreed to the published version of the manuscript.

Funding: This research has the financial support of the Government of Aragón and of the European Social Fund (FEDER) under grant Gespublica S56_20R.

Institutional Review Board Statement: Not applicable.

Informed Consent Statement: Not applicable.

Data Availability Statement: Data sharing not applicable.

Conflicts of Interest: The authors declare no conflict of interest.

\section{Appendix A}

Discretionary Accruals (DA) are accounting accruals that differ from accruals that are expected according to the entity's activity (non-discretionary accruals, NDA). DA can be expressed as follows:

$$
\text { DAjt }=\text { Ajt }- \text { NDAjt, }
$$

where $A$ is total accounting accruals, and $\mathrm{j}$ and $\mathrm{t}$ denote observation $\mathrm{j}$ and year $\mathrm{t}$.

Jones (1991), modified Jones (Dechow et al., 1995) and Kasznik (1999), as in Equations (A2), (A3) and (A4), respectively.

$$
\begin{gathered}
\mathrm{A}_{\mathrm{jt}} / \mathrm{TA}_{\mathrm{jt}-1}=\alpha_{1}\left(1 / \mathrm{TA} \mathrm{A}_{\mathrm{jt}-1}\right)+\alpha_{2}\left(\Delta \mathrm{REV}_{\mathrm{jt}} / \mathrm{TA}_{\mathrm{jt}-1}\right)+\alpha_{3}\left(\mathrm{PPE}_{\mathrm{jt}} / \mathrm{TA} \mathrm{A}_{\mathrm{jt}-1}\right)+\varepsilon_{\mathrm{jt}} \\
\mathrm{A}_{\mathrm{jt}} / \mathrm{TA}_{\mathrm{jt}-1}=\beta_{1}\left(1 / \mathrm{TA}_{\mathrm{jt}-1}\right)+\beta_{2}\left(\Delta \mathrm{REV}_{\mathrm{jt}}-\Delta \mathrm{AR}_{\mathrm{jt}}\right) / \mathrm{TA}_{\mathrm{jt}-1}+\beta_{3}\left(\mathrm{PPE}_{\mathrm{jt}} / \mathrm{TA}_{\mathrm{jt}-1}\right)+\varphi_{\mathrm{jt}} \\
\mathrm{A}_{\mathrm{jt}} / \mathrm{TA}_{\mathrm{jt}-1}=\delta_{1}+\delta_{2}\left(\Delta \mathrm{REV}_{\mathrm{jt}}-\Delta \mathrm{AR}_{\mathrm{jt}}\right) / \mathrm{TA}_{\mathrm{jt}-1}+\delta_{3}\left(\mathrm{PPE}_{\mathrm{jt}} / \mathrm{TA}_{\mathrm{jt}-1}\right)+\delta_{1}\left(\Delta \mathrm{CFO}_{\mathrm{jt}} / \mathrm{TA}_{\mathrm{jt}-1}\right)+\gamma_{\mathrm{jt}} \\
\text { where, } \\
\mathrm{A}_{\mathrm{jt}}=\text { Total accruals for agency } \mathrm{j} \text { in year } \mathrm{t}, \\
\mathrm{TA}_{\mathrm{jt}-1}=\text { Total assets for agency } \mathrm{j} \text { at the end of year } \mathrm{t}-1 \\
\Delta \mathrm{REV}_{\mathrm{jt}}=\text { Change in revenues for agency } \mathrm{j} \text { in year } \mathrm{t}, \\
\Delta \mathrm{AR}_{\mathrm{jt}}=\text { Change in accounts receivable for agency } \mathrm{j} \text { in year } \mathrm{t} \\
\mathrm{PPE}_{\mathrm{jt}}=\text { Gross property, plant and equipment for agency j in year } \mathrm{t} \\
\Delta \mathrm{CFO}_{\mathrm{jt}}=\text { Change in cash flow from operating activities for agency } \mathrm{j} \text { in year } \mathrm{t} .
\end{gathered}
$$




\section{References}

1. Agrawal, A.; Chadha, S. Corporate governance and accounting scandals. J. Law Econ. 2005, 48, 371-406. [CrossRef]

2. Jensen, M.C. The modern industrial revolution, exit, and the failure of internal control systems. J. Financ. 1993, 48, 831-880. [CrossRef]

3. Torchia, M.; Calabrò, A. Board of directors and financial transparency and disclosure. Evidence from Italy. Corp. Gov. 2016, 16, 593-608. [CrossRef]

4. Bhagat, S.; Black, B. The non-correlation between board independence and long-term firm performance. J. Corp. Law 2002, 27, 231-273. [CrossRef]

5. Borisova, G.; Brockman, P.; Salas, J.M.; Zagorchev, A. Government ownership and corporate governance: Evidence from the EU. J. Bank. Financ. 2012, 36, 2917-2934. [CrossRef]

6. Chartered Institute of Public Finance and Accountancy. Corporate Gov.: A Framework for Public Service Bodies; Chartered Institute of Public Finance and Accountancy: London, UK, 1995.

7. Nolan, M. The Seven Principles of Public Life; First Report of the Committee on Standards in Public Life; UK Government: London, UK, 1995.

8. Tricker, R.I. Corporate Gov. Principles, Policies and Practices; Oxford University Press: Oxford, UK, 2012.

9. Australian National Audit Office. Better Practice Public Sector Gov.; National Institute for Governance: Camberra, Australia, 2003.

10. Pina, V.; Arcas, M.J.; Martí, C. Accruals and accounting numbers management in the UK executive agencies. Public Money Manag. 2012, 32, 273-280. [CrossRef]

11. Laswad, F.; Fisher, R.; Oyelere, P. Determinants of voluntary internet financial reporting by local government authorities. J. Account. Public Policy 2005, 24, 101-121. [CrossRef]

12. Filgueiras, F. Transparency and accountability: Principles and rules for the construction of publicity. J. Public Aff. 2015, 16, 192-202. [CrossRef]

13. van Slyke, D.M. Agents or Stewards: Using Theory to Understand the Government-Nonprofit Social Service Contracting Relationship. J. Public Adm. Res. Theory 2006, 17, 157-187. [CrossRef]

14. Schillemans, T. Moving Beyond the Clash of Interests: On stewardship theory and the relationships between central government departments and public agencies. Public Manag. Rev. 2013, 15, 541-562. [CrossRef]

15. Hinna, A.; De Nito, E.; Mangia, G. Board of directors within public organisations: A literature review. Int. J. Bus. Gov. Ethic. 2010, 5, 131-156. [CrossRef]

16. Lane, J.E. Public Administration and Public Management: The Principal-Agent Perspective; Taylor \& Francis: New York, NY, USA, 2005.

17. Calabro, A.; Torchia, M.; Ranalli, F. Ownership and control in local public utilities. J. Manag. Gov. 2013, 17, 835-862. [CrossRef]

18. Shawtari, F.A.; Mohamad, M.H.; Rashid, H.S.; Ayedh, H.M. Board characteristics and real performance in Malaysian state-owned enterprises (SOEs). Int. J. Prod. Perform. Manag. 2017, 66, 1064-1086. [CrossRef]

19. Batley, R.; Larbi, G. The Changing Role of Government: The Reform of Public Services in Developing Countries; Springer: New York, NY, USA, 2004.

20. Gnan, L.; Hinna, A.; Monteduro, F.; Scarozza, D. SOEs ownership and control: Independence and competence of boards members. Corp. Ownersh. Control. 2011, 8, 720-739. [CrossRef]

21. Schillemans, T.; Bjurstrøm, K.H. Trust and Verification: Balancing Agency and Stewardship Theory in the Governance of Agencies. Int. Public Manag. J. 2020, 23, 650-676. [CrossRef]

22. Caers, R.; Du Bois, C.; Jegers, M.; De Gieter, S.; Schepers, C.; Pepermans, R. Principal-Agent Relationships on the StewardshipAgency Axis. Nonprofit Manag. Leadersh. 2006, 17, 25-47. [CrossRef]

23. Keay, A. Stewardship theory: Is board accountability necessary? Int. J. Law Manag. 2017, 59, 1292-1314. [CrossRef]

24. Davis, J.H.; Schoorman, F.D.; Donaldson, L. Toward a Stewardship Theory of Management. Acad. Manag. Rev. 1997, 22, 20-47. [CrossRef]

25. Bjurstrøm, K.H. Principal-Agent or Principal-Steward:How Ministry-Agency Relations Condition the Impact of Performance Management in the Steering of Government Agencies. Public Perform. Manag. Rev. 2020, 43, 1053-1077. [CrossRef]

26. Kyere, M.; Ausloos, M. Corporate governance and firms financial performance in the United Kingdom. Int. J. Finance Econ. 2020. [CrossRef]

27. Ashforth, B.E.; Gibbs, B.W. The double-edge of organizational legitimation. Organ. Sci. 1990, 1, 177-193. [CrossRef]

28. Suchman, M.C. Managing legitimacy: Strategic and institutional approaches. Acad. Manag. Rev. 1995, 20, 571-606. [CrossRef]

29. Freeman, R.E.; Reed, D.L. Stockholders and stakeholders: A new perspective on corporate governance. Calif. Manag. Rev. 1983, 25, 88-106. [CrossRef]

30. Freeman, R.E. Strategic Management: A Stakeholder Approach; Pitman: Boston, MA, USA, 1984.

31. Donaldson, T.; Preston, L.E. The stakeholder theory of the corporation: Concepts, evidence and implications. Acad. Manag. Rev. 1995, 20, 65-91. [CrossRef]

32. Michelon, G.; Parbonetti, A. The effect of corporate governance on sustainability disclosure. J. Manag. Gov. 2012, 16, 477-509. [CrossRef]

33. Torfing, J.; Bentzen, T.Ø. Does Stewardship Theory Provide a Viable Alternative to Control-Fixated Performance Management? Adm. Sci. 2020, 10, 86. [CrossRef] 
34. Luke, B. Examining Accountability Dimensions in State-Owned Enterprises. Financ. Account. Manag. 2010, 26, 134-162. [CrossRef]

35. Royo, S.; Yetano, A.; García-Lacalle, J. Accountability Styles in State-Owned enterprises: The good, the bad, the ugly... And the pretty. Rev. Contab. Span. Account. Rev. 2019, 22, 156-170. [CrossRef]

36. Arcas, M.J.; Martí, C. Financial Performance Adjustment in English Local Governments. Aust. Account. Rev. 2016, $26,141-152$. [CrossRef]

37. Guest, P.M. The impact of board size on firm performance: Evidence from the UK. Eur. J. Financ. 2009, 15, 385-404. [CrossRef]

38. Coy, D.; Fischer, M.; Gordon, T. Public accountability: A new paradigm for college and university annual reports. Crit. Perspect. Account. 2011, 12, 1-31. [CrossRef]

39. García-Meca, E.; Sánchez-Ballesta, J.P. Corporate Governance and Earnings Management: A Meta-Analysis. Corp. Gov. Int. Rev. 2009, 17, 594-610. [CrossRef]

40. Saona, P.; Muro, L.; Alvarado, M. How do the ownership structure and board of directors' features impact earnings management? The Spanish case. J. Int. Financ. Manag. Account. 2020, 31, 98-133. [CrossRef]

41. García-Sánchez, I.M.; Rodríguez-Domínguez, L.; Gallego-Álvarez, I. Corporate governance and strategic information on the internet: A study of Spanish listed companies. Account. Audit. Account. J. 2011, 24, 471-501. [CrossRef]

42. Bueno, G.; Marcon, R.; Pruner-da-Silva, A.L.; Ribeirete, F. The role of the board in voluntary disclosure. Corp. Gov. 2018, 18, 886-910. [CrossRef]

43. Pina, V.; Torres, L. Online transparency and corporate governance in Spanish governmental agencies. Online Inf. Rev. 2019, 43, 653-675. [CrossRef]

44. Pina, V.; Torres, L.; Yetano, A. Accrual accounting in EU local governments: One method, several approach. Eur. Account. Rev. 2009, 18, 765-807. [CrossRef]

45. Jensen, M.C.; Meckling, W.H. Theory of the firm: Managerial behavior, agency costs and ownership structure. J. Financ. Econ. 1976, 3, 305-360. [CrossRef]

46. Anthony, R.N. Games government accountants play. Harv. Bus. Rev. 1985, 63, 161-170.

47. Stalebrink, O.J.; Sacco, J.F. Rationalization of Financial Statement Fraud in Government: An Austrian Perspective. Crit. Perspect. Account. 2007, 18, 489-507. [CrossRef]

48. Easterly, W.; de Haan, J.; Gali, G. When is fiscal adjustment an illusion? Econ. Policy 1999, 14, 57-86. [CrossRef]

49. Petersen, J.E. Changing red to black: Deficit closing alchemy. Natl. Tax J. 2003, 56, 567-577. [CrossRef]

50. Capalbo, F.; Frino, A.; Mollica, V.; Palumbo, R. Accrual-based earnings management in state owned companies. Implications for transnational accounting regulation. Account. Audit. Account. J. 2014, 27, 1026-1040. [CrossRef]

51. Ellwood, S.; Garcia-Lacalle, J. The influence of presence and position of women on the boards of directors: The case of NHS foundation trusts. J. Bus. Ethic. 2015, 130, 69-84. [CrossRef]

52. Albalate del Sol, D. The institutional, economic and social determinants of local government transparency. J. Econ. Policy Reform 2013, 16, 90-107.

53. Eisenhardt, K.M.; Schoonhoven, C.B. Organizational growth: Linking founding team, strategy, environment, and growth among US semiconductor ventures, 1978-1988. Adm. Sci. Q. 1990, 35, 504-529. [CrossRef]

54. Zimmerman, J.L. The municipal accounting maze: An analysis of political incentives. J. Account. Res. 1977, 15, 107-144. [CrossRef]

55. Watts, R.L.; Zimmerman, J.L. Positive Accounting Theory; Prentice-Hall International: London, UK, 1986.

56. NAO. Improving Service Delivery: The Role of Executive Agencies; National Audit Office: London, UK, 2003.

57. García-Juanatey, A.; Jordana, J.; Parrado, S.; Pascual, L.; Salvador, M.; Sancho, D. Las agencias públicas en España: Percepciones sobre autonomía y rendición de cuentas. Rev. Esp. Cienc. Política 2017, 43, 61-82. [CrossRef]

58. Klein, A. Audit committee, board of director characteristics, and earnings management. J. Account. Econ. 2002, 33, 375-400. [CrossRef]

59. Larcker, D.; Richardson, S. Fees paid to audit firms, accrual choices, and corporate governance. J. Account. Res. 2004, 42, 625-658. [CrossRef]

60. Larcker, D.; Richardson, S.; Tuna, I. Corporate governance, accounting outcomes and organizational performance. Account. Rev. 2007, 82, 963-1008. [CrossRef]

61. Peterson, K.; Schmardebeck, R.; Wilks, T.J. The Earnings Quality and Information Processing Effects of Accounting Consistency. Account. Rev. 2015, 90, 2483-2514. [CrossRef]

62. Myers, J.N.; Myers, L.A.; Omer, T.C. Exploring the term of the auditor-client relationship and the quality of earnings: A case for mandatory auditor rotation? Account. Rev. 2003, 78, 779-799. [CrossRef]

63. Serrano-Cinca, C.; Fuertes, Y.; Gutierrez, B. Online reporting by banks: A structural modelling approach. Online Inf. Rev. 2007, 31, 310-332. [CrossRef]

64. Hair, J.F.; Sarstedt, M.; Ringle, C.M.; Mena, J.A. An assessment of the use of partial least squares structural equation modeling in marketing research. J. Acad. Mark. Sci. 2012, 40, 414-433. [CrossRef]

65. Ntim, C.G.; Soobaroyen, T.; Broad, M.J. Governance structures, voluntary disclosures and public accountability: The case of UK higher education institutions. Account. Audit. Account. J. 2017, 30, 65-118. [CrossRef]

66. Coffey, B.S.; Wang, J. Board diversity and managerial control as predictors of corporate social performance. J. Bus. Ethic. 1998, 17, 1595-1603. [CrossRef] 
67. van Knippenberg, D.; De Dreu, C.K.V.; Homan, A.C. Work group diversity and group performance: An integrative model and research agenda. J. Appl. Psychol. 2004, 89, 1008-1022. [CrossRef]

68. Carter, D.A.; Betty, J.S.; Simpson, W.G. Corporate governance, board diversity, and firm value. Financ. Rev. 2003, 38, 33-53. [CrossRef]

69. Ye, K. Independent director cash compensation and earnings management. J. Account. Public Policy 2014, 33, 391-400. [CrossRef]

70. Roldán, J.; Sánchez-Franco, M. Variance-based structural equation modeling: Guidelines for using Partial Least Squares in information systems research. In Research Methodologies, Innovations and Philosophies in Software Systems Engineering and Information Systems; Mora, M., Gelman, O., Steenkamp, A.L., Raisinghani, M., Eds.; IGI Global: Hershey, RI, USA, $2012 ;$ pp. $193-221$.

71. Nunnally, J.C. Psychometric Theory; McGraw Hill: New York, NY, USA, 1978.

72. Malloy, D.C.; Agarwal, J. Ethical climate in government and nonprofit sectors: Public policy implications for service delivery. J. Bus. Ethic. 2010, 94, 3-21. [CrossRef]

73. Bagozzi, R.P.; Yi, Y. On the evaluation of structural equation models. J. Acad. Mark. Sci. 1988, 16, 74-94. [CrossRef]

74. Chartered Institute of Public Finance and Accountancy. Good Gov. Standard for Public Services; Chartered Institute of Public Finance and Accountancy: London, UK, 2004. 